\title{
LIQUEFACTION POTENTIAL IN THE ADRIATIC COASTAL AREAS IN ALBANIA
}

\author{
Daja Sh. ${ }^{1}$, Ago B. ${ }^{2}$ and Muci R. ${ }^{3}$. \\ ${ }^{1}$ Polytechnic University of Tirana, Faculty of Geology and Mining, Albania, \\ shkelqim.daja@fgjm.edu.al \\ ${ }^{2}$ Polytechnic University of Tirana, Faculty of Geology and Mining - PHD School, Albania, \\ besiago@live.com \\ ${ }^{3}$ Polytechnic University of Tirana, Faculty of Geology and Mining, Albania, \\ redi.muci@fgjm.edu.al
}

\begin{abstract}
The objective of this study is the evaluation of the phenomenon of liquefaction along the coastal area west of Albania. The study is based on the combination of qualitative approach which use geological criteria as the type of soil, their age, hydrogeological conditions and seismicity of the area and quantitative or deterministic approaches consisting on the evaluation of Liquefaction Potential Index (LPI). The quantitative analysis is based on the CPTU data. Three hazard levels, corresponding to different levels of safety such as $50 \%$ in 50 years (72-years Return Period), $10 \%$ in 50 years (475-years RP) and 2\% in 50 years (2475-years RP), have been taken into consideration. The results of the deterministic approaches yielded further evidence of high potential of liquefaction, which suggests the same level of susceptibility for other areas of the same geological conditions and stress history. These areas are mapped based on Geotechnical Map of Albania.
\end{abstract}

Keywords: Liquefaction potential index, cone penetration test, hazard Albania.

\section{Introduction}

Liquefaction is a phenomenon that causes the loss of shear strength and stiffness of soils during a seismic shaking as a result of increased pore water pressure accompanied by the reduction of effective stresses. The soil no longer behaves like a solid, rather it acts as a viscous fluid. As the bearing capacity of the soil to sustain foundation loads is related to strength, liquefaction poses a serious hazard to structures and must be assessed in areas where liquefaction prone deposits exist. The types of soil that are more prone to liquefaction are loose saturated silts and sands below the groundwater table at a depth of less than 20 meters, generally dating from the Holocene Age. Some very important urban centres, such as Durres, Vlora etc., are resting on these kinds of deposits. In recent years, new urban centres were developed into previously uninhabited areas such as the coast from Shkëmbi i Kavajës to Karpen, Lalëzi Bay etc. The geological-engineering studies for the construction of new buildings are based on the Albanian Technical Code KTP-5-78, which does not explicitly require the evaluation of this phenomenon as part of the study. The Seismic Design Code KTP-N2-89 is limited only to the classification of the soil conditions into three categories, I, II, and III, which should be determined based on the seismic microzoning studies and the respective engineering geological studies. The category of soil is used only to evaluate the seismic excitation 
of a construction according to the expected seismic intensity (MSK-64) and the liquefaction criterion is not a code requirement during the seismic design. Actually, the Albanian practice of foundation design doesn't consider the liquefaction phenomenon. Under such conditions, the construction of shallow foundations in liquefaction prone areas, without applying any soil improvement techniques, may lead to high vulnerability of structures in the event of a seismic shaking.

\section{Methodology}

In order to evaluate the liquefaction potential qualitative and quantitative methods were used.

\subsection{Qualitative analysis}

Firstly in this study the identification the areas consisting of soils susceptible to the phenomenon by using qualitative criteria such as the soil type, hydrogeological conditions, seismic activity and the occurrence of previous liquefaction phenomena.

In general, are considered as liquefiables the soils that fulfil the following conditions (Riga, 2008):

- Groundwater table less than $15 \mathrm{~m}$ from the surface.

- Holocene deposits (sands, silty sands or clayey sands).

- Evidence of previous liquefaction events in the past.

- High seismicity of the area.

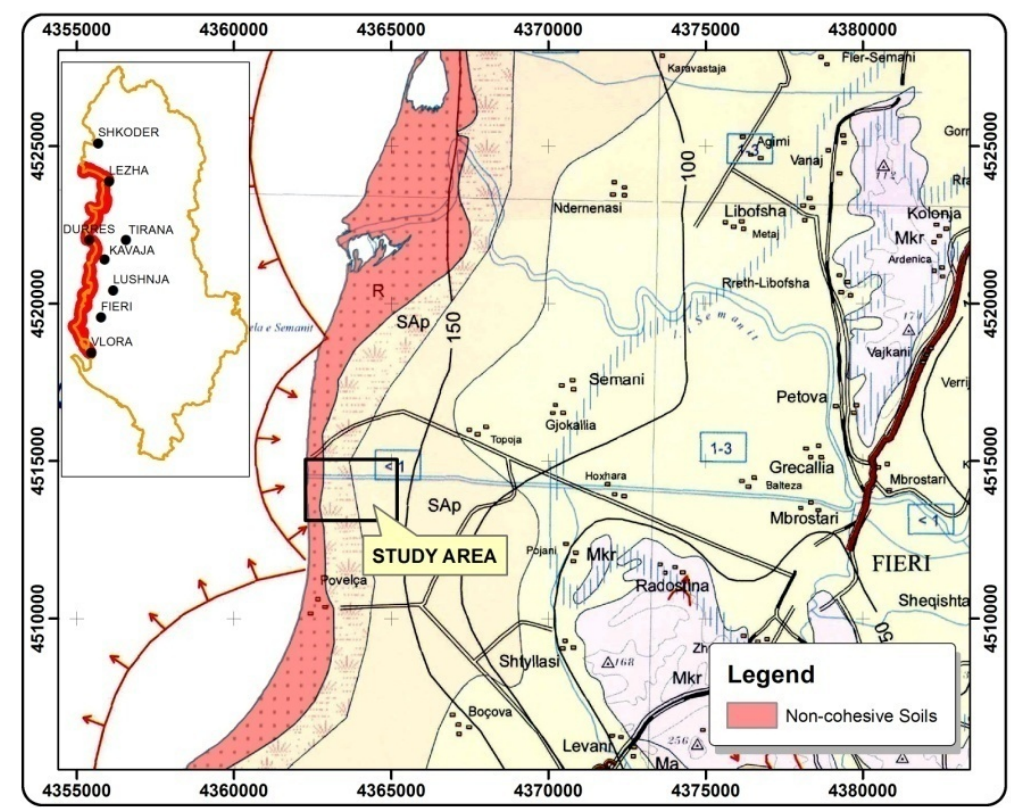

Figure 1 - Non - cohesive soils distribution in the Albanian coastal areas.

Based on the Geotechnical Map of Albania at 1:200000 scale, the abovementioned criteria are met along a coastal belt from Vlora to Velipoja which comprises a surface area of around $170 \mathrm{~km}^{2}$ (Figure 1). For these areas deterministic analysis are necessary in order to determine the liquefaction potential. 


\subsection{Quantitative analyses}

Quantitative analyses were carried out in an area of study that is close to Fier. The liquefaction assessment is conducted using the Cone Penetration Test (CPTU) which is considered to be a reliable device for soil investigation by today's standards, providing important information on soil type and geotechnical parameters. The employed evaluation methodology consists on the use of equations proposed by various authors (Seed and Idriss, 1971; Iwasaki, 1982; Liao and Whitman, 1986; Robertson and Wride, 1998; Sonmez, 2003; etc.).

\subsubsection{Liquefaction potential index (LPI)}

The Liquefaction Potential Index calculations utilize safety factors, which are defined as the ratio of the Cyclic Resistance Ratio (CRR) to the Cyclic Stress Ratio (CSR).

LPI parameter was proposed by Iwasaki (1978) which relies on the in situ test data over the entire borehole (or more accurately, the top $20 \mathrm{~m}$ ) as follows:

$$
L P I=\int_{0}^{20} F(z) \times w(z) d z
$$

Where $F(z)=0$ if $F S L>1$ and $F(z)=1-F S L$ if $F S L<1$

$$
w(z)=10-0.5 \times z
$$

$\mathrm{z}$ - Being the soil depth in (m)

Iwasaki (1982) concluded that severe liquefaction is very likely to happen at sites with LPI greater than 15 and that liquefaction is unlikely at sites with LPI less than 5.

Sonmez (2003) proposed a modification to Iwasaki's 1.0 threshold for FSL and instead suggested that the interval from 1.0 to 1.2 of FSL values should be also considered in analysing the liquefaction potential of soils. Hence he modified the equations and susceptibility classes as follows:

$$
\begin{array}{ll}
F(z)=0 & \text { if } F S L \geq 1.2 \\
F(z)=2 \cdot 10^{6} \cdot \exp (-18.427 \cdot F S L & \text { if } 1.2>F S L>0.95 \\
F(z)=1-F S L & \text { if } F S L \leq 0.95
\end{array}
$$

Table 1 - Modified liquefaction susceptibility classes (Sonmez, 2003).

\begin{tabular}{|l|l|}
\hline \multicolumn{1}{|c|}{$\begin{array}{c}\text { Liquefaction Potential Index } \\
\text { (LPI) }\end{array}$} & \multicolumn{1}{|c|}{$\begin{array}{c}\text { Liquefaction Potential } \\
\text { (Susceptibility) }\end{array}$} \\
\hline$L P I=0$ & Non - liquefiable \\
\hline $0<L P I \leq 2$ & Low \\
\hline $2<L P I \leq 5$ & Moderate \\
\hline $5<L P I \leq 15$ & High \\
\hline$L P I>15$ & Very High \\
\hline
\end{tabular}

\subsubsection{The safety factor against liquefaction}

The safety factor is defined as the ratio of the Cyclic Resistance Ratio (CRR) to the Cyclic Stress Ratio (CSR). 


$$
F S L=\frac{C R R}{C S R}
$$

\section{Cyclic stress ratio, CSR}

The average uniform cyclic stress ratio (CSR) within a liquefiable layer is given by Seed and Idriss (1971):

$$
C S R=\frac{\tau_{a v}}{\sigma_{v o}}=0.65 \cdot\left(\frac{a_{\max }}{g}\right) \cdot\left(\frac{\sigma_{v o}}{\sigma_{v o}^{\prime}}\right) \cdot r_{d}
$$

Where: $\sigma_{V 0}$ and $\sigma_{V 0}^{\prime}$ are the total overburden stress and total effective stress, respectively; $\mathrm{a}_{\max }{ }^{-}$ peak horizontal acceleration at the ground surface; g-gravity acceleration and $r_{d}$ - is the stress reduction coefficient.

Three hazard levels, corresponding to different levels of safety such as $50 \%$ in 50 years (72-years Return Period), $10 \%$ in 50 years (475-years RP) and $2 \%$ in 50 years (2475-years RP), have been taken into consideration. The maximum accelerations (PGA) corresponding to the mentioned hazard levels are calculated using PSHA (Probabilistic Seismic Hazard Assessment), considering earthquakes with $M_{S} \geq 4.5$ covering a time span from year 58 up to 2009. The estimated PGA values, used in CSR calculation are $0.25 \mathrm{~g}, 0.391 \mathrm{~g}$ and $0.488 \mathrm{~g}$, respectively.

The relations proposed by Liao and Whitman (1986) use a function of $r_{d}$ that is dependent only on the soil depth as follows:

$$
r_{d}=1.0-0.00765 \mathrm{z} \quad \text { if } \mathrm{z}<9.15 \mathrm{~m} \quad r_{d}=1.174-0.0267 \mathrm{z} \text { if } \mathrm{z}=9.15 \text { to } 23 \mathrm{~m}
$$

\section{Cyclic resistance ratio CRR 7.5 based on CPT data}

For the cyclic resistance ratio of clean sands and a magnitude of 7.5 (CRR7.5), Robertson and Wride (1998) have proposed the following equations:

$$
\begin{aligned}
& C R R_{7.5}=0.833\left[\left(q_{c 1 N}\right)_{c s} / 1000\right]+0.05 \quad \text { for }\left(q_{c 1 N}\right)_{c s}<50 \\
& C R R_{7.5}=93\left[\left(q_{c 1 N}\right)_{c s} / 1000\right]^{3}+0.08 \quad \text { for } 50 \leq\left(q_{c 1 N}\right)_{c s}<160
\end{aligned}
$$

With $\left(\mathrm{q}_{\mathrm{c} 1 \mathrm{~N}}\right)_{\mathrm{CS}}$ being the normalized cone penetration resistance, corrected for the fine content influence as follows:

$$
\left(q_{c 1 N}\right)_{c s}=K_{c}^{*} q_{c 1 N}
$$

Where $\left(\mathrm{q}_{\mathrm{c} 1 \mathrm{~N}}\right)$ is the normalized (stress-adjusted) cone penetration resistance defined as follows:

$$
\left(q_{c 1 N}\right)_{c s}=C_{q} *\left(q_{c} / P_{a}\right)
$$

$$
C_{q}=\left(P_{a}-\sigma_{v 0}^{\prime}\right)^{n} \text { Being the normalized tip resistance factor. }
$$

$K c$ is the correction factor for particle size characteristics, defined by the following equation (Robertson and Wride, 1998):

$$
\begin{array}{ll}
K_{c}=1.0 & \text { for } I_{c} \leq 1.64 \\
K_{c}=-0.403 I_{c}^{4}+5.581 I_{c}^{3}-21.63 I_{c}^{2}+33.75 I_{c}-17.88 & \text { for } I_{c}>1.64
\end{array}
$$


The soil behaviour type index, Ic, defined by Robertson and Wride (1998) is computed as follows:

$$
I_{c}=\left[(3.47-\log Q)^{2}+(1.22+\log F)^{2}\right]^{0.5}
$$

Where: $Q=\left[\left(q_{c}-\sigma_{v 0}\right) / P_{a}\right] *\left[\left(P_{a} / \sigma_{v 0}\right)^{n}\right]$ - is the normalized cone penetration resistance,

and $F=\left[f_{s} /\left(q_{c}-\sigma_{v 0}\right)\right] * 100 \%$ the normalized friction ratio.

Where: $\mathrm{Pa}$ is the atmospheric pressure; $\mathrm{q}_{\mathrm{c}}$ is the measured tip resistance and $\mathrm{f}_{\mathrm{s}}$ is the CPT sleeve friction resistance.

The stress exponent " $\mathrm{n}$ " varies in relation to the soil type. The typical values of " $\mathrm{n}$ " are 0.5 for clean sands and 1 for clays. For silts and silty sands a value intermediate between 0.5 and 1.0 is appropriate. An iteration procedure proposed by Robertson (1990) is used to evaluate " $n$ " and consequently the soil behaviour type index Ic.

\section{Cyclic resistance ratio for the maximum observed magnitude $C_{R R}$}

The cyclic resistance ratio for the maximum recorded magnitude is scaled by introducing the magnitude scaling factor (MSF) as proposed by Idriss (1990):

$$
M S F=10^{2.24} / M^{2.56}
$$

\section{Application}

The deterministic procedure described above was applied in a coastal area located in the Southern part of the Eastern Adriatic Coastline near Fieri Municipality in Albania (Figure 2). The Quaternary's deposits are represented by gravels, sands, silty sands, silty clays, and clays. These deposits have a thickness of more than $100 \mathrm{~m}$ and the water table varies from $0.5 \mathrm{~m}$ to $1.0 \mathrm{~m}$ below the ground surface. The liquefaction assessment is conducted using the Cone Penetration Test (CPTU) results. 12 soil profiles based on Soil Behaviour Type Index (Ic) are used to calculate the Liquefaction Potential Index (LPI) (Figure 3).

The study area is included in the Periadriatic Depression, denoted as PL-zone, strongly affected by post-Pliocene compressional movements (Aliaj, 2012). This area represents the westernmost frontal part of the compressional domain, in direct convergence with Adria microplate and is characterized by a high seismic activity.

According to the seismic regionalization of Albania, the expected earthquake magnitudes of the area vary from 5.5 to 5.9. The highest magnitude $(\mathrm{Ms}=6.0)$ recorded to date refers to the Fier earthquake of 18/03/1962, during which the liquefaction phenomena occurred, causing a lateral spreading up to several dozen centimeters, and reaching a length of $100 \mathrm{~m}$ (Aliaj et al., 2010).

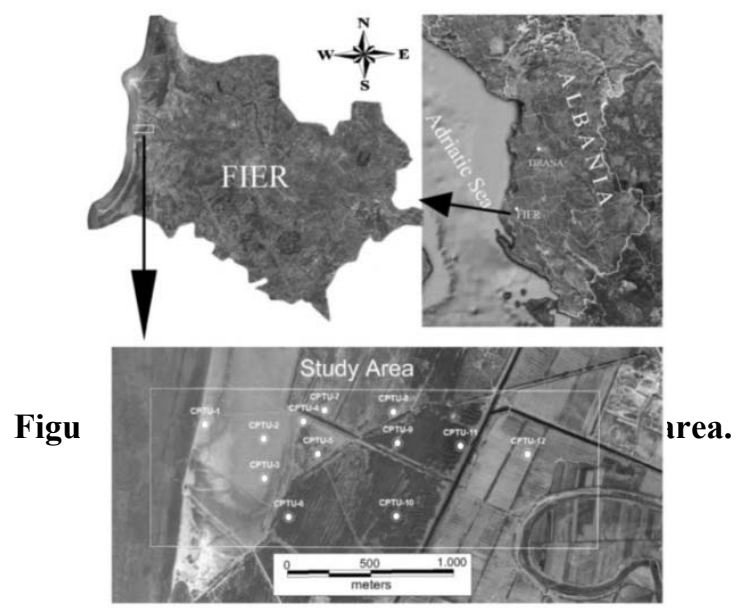




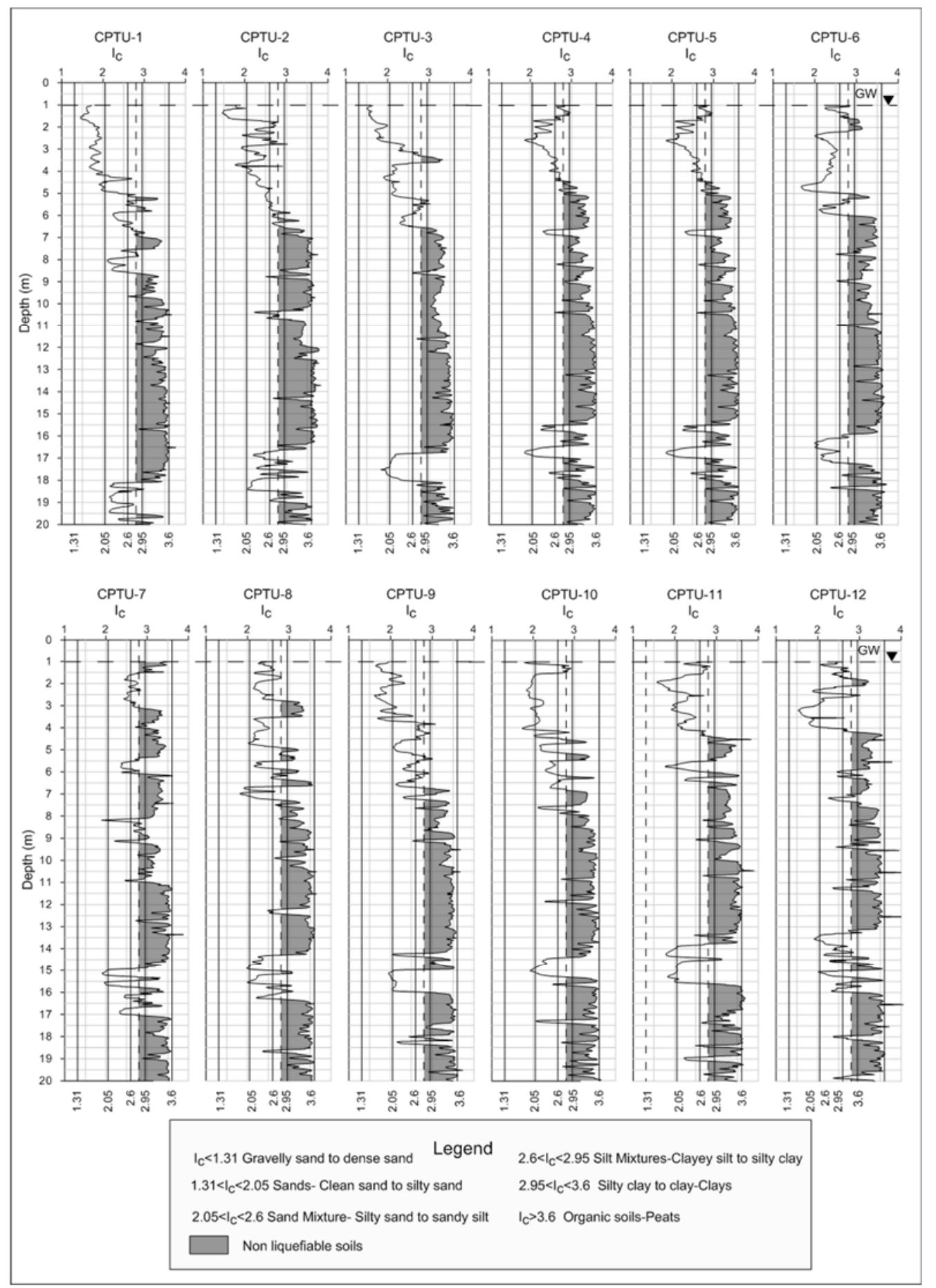

Figure 3 - Soil profiles based on Soil Behaviour Type Index (Ic). 


\section{Results and conclusions}

The results of the deterministic analysis are shown in the figure 3 as maps of LPI (liquefaction potential index) variations for the first hazard level (Figure 3a), for the second and third hazard level respectively in the Figures $3 \mathrm{~b}$ and $3 \mathrm{c}$.

The LPI values vary from 7.7 to 16.86 for the first seismic hazard level, suggesting a high to very high liquefaction susceptibility. For the second and the third seismic hazard levels the LPI values vary respectively from 15.01 to 26.95 and 17.10 to 30.62 corresponding to very high liquefaction susceptibility.

These results also show that due to the heterogeneity of soils, variations of the LPI can be observed even in short distances.

Although part of the detailed study area, according to the geotechnical map is composed of cohesive soils near the surface, a high liquefaction potential is observed for all three levels of seismic hazard suggesting that the coastal zone susceptible to liquefaction phenomenon stretches farther than the one delineated in the map. 
As conclusion we can say that same results can be expected in areas with similar geological conditions and stress history, soliciting the need to study the phenomenon in the entire coastal area of Albania.
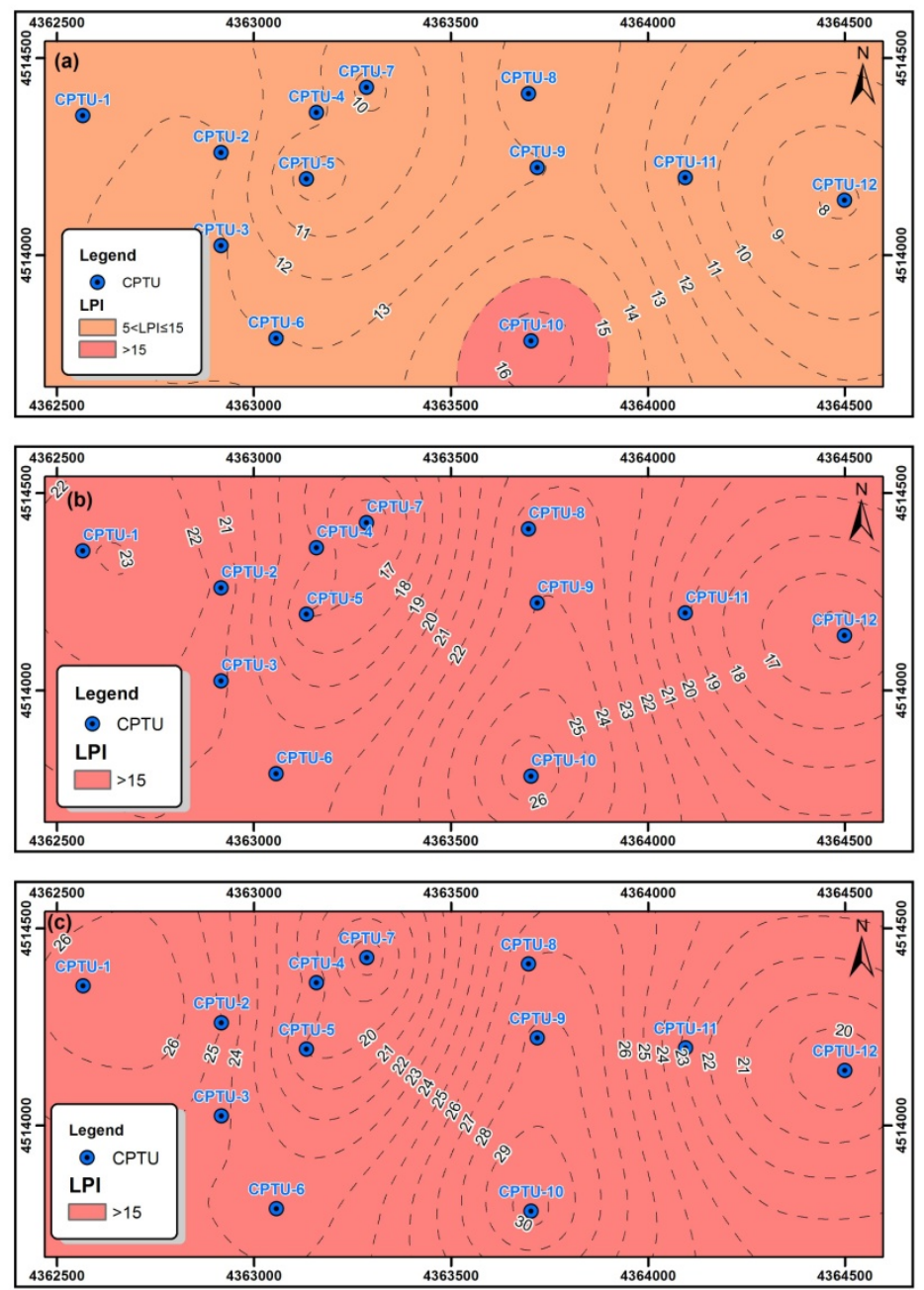

Figure 4 - Maps of LPI for the first hazard level (a), second hazard level (b) and third hazard level (c).

\section{References}

Aliaj, S., Koçiu, S., Muço, B. and Sulstarova, E., 2010. Sizmicteti, sizmotektonika dhe vleresimi i rrezikut sizmik ne Shqipëri (Seismicity, seismotectonics and seismic hazard assessment in Albania), Akademia e Shkencave e Shqiperise.

Aliaj, S., 2012. Neotektonika e Shqiperise (Neotectonic of Albania).

Chen, C.J. and Juang, C.H., 2000. Calibration of SPT and CPT-based liquefaction evaluation methods, ASCE, Reston, VA, 49-64.

Daja S., Shkodrani, N., Lako, A. and Ago, B., 2013. Real liquefaction probability of non-cohesive soils in Semani area, in Albania, Ital. J. Geosci. (Boll. Soc. Geol. It.), 132(2), 213-219.

Idriss, I.M., 1990. Response of soft soil sites during earthquakes. Proc., H. Bolton Seed Memorial Symp., Vol. 2, BiTech Publishers, Ltd., Vancouver, 273-290. 
Iwasaki, T., Tatsuoka, F., Tokida, K. and Yasuda, S., 1978. A practical method for assessing soil liquefaction potential based on case studies at various sites in Japan, Proceedings, $2^{\text {nd }}$ International Conference on Microzonation, San Francisco, 885-896.

Iwasaki, T., Arakawa, T. and Tokida, K., 1982. Simplified procedures for assessing soil liquefaction during earthquakes, Proceedings of the Conference on Soil dynamics and Earthquake Engineering, Southampton, UK, 925-939.

Juang, C.H., Jiang, T. and Andrus, R.D., 2002. Assessing probability-based methods for liquefaction evaluation, Journal of Geotechnical and Geoenvironmental Engineering, ASCE, 128(7), 690702 .

Konomi, N. et al., 2014. Geological Engineering Map of Albania at 1:200000 scale.

Liao, S.S.C. and Whitman, R.V., 1986b. Catalogue of a Liquefaction and Non-Liquefaction Occurrences During Earthquakes, Research Report, Dept. Of Civil Engineering, M.I.T., Cambridge, MA.

Riga, Giulio, 2008. Microzonazione sismica: procedure di I, II e III livello. Dario Flaccovio Editore, ISBN 978-88-7758-797-8.

Robertson, P.K., 1990. Soil classification using the cone penetration test, Canadian Geotechnical Journal, 27(1), 151-8.

Robertson, P.K. and Wride, C., 1998. Evaluating cyclic liquefaction potential using the cone penetration test, Canadian Geotechnical Journal, 35(3), 442-459.

Seed, H.B. and Idriss, I.M., 1971. Simplified procedure for evaluating soil liquefaction potential, Journal of Geotechn. Engin. Division, ASCE, 97(9), 1249-1273.

Toprak S., Asce, A.M. and Holzer, T.L, 2003. Liquefaction Potential Index: Field Assessment, Journal of Geotechnical and Geoenvironmental Engineering, 129(4), 2003.

Shkodrani, N., Daja, S. and Ormeni, R., 2010. Engineering Characteristics of the Expected Shaking at Semani Site in Albania, ACEE, Proc. 3rd Asia Conference on Earthquake Engineering, Disaster Risk Reduction and Capacity Building for Safer Environments, Bangkok, Thailand 01-03 December 2010.

Sulstarova, E., Kociaj, S. and Aliaj, Sh., 1980. Seismic Regionalization of PSR of Albania, Publication of Academy of Sciences, Tirana-Albania, $297 \mathrm{pp}$.

Sulstarova, E., Kociaj, S., Muco, B. and Peci V., 2003. The Albanian earthquakes catalogue for historical and instrumental data with magnitude $\mathrm{Ms} \geq 4.5$, Seismological Institute, Tirana, Albania.

Sonmez, H., 2003. Modification to the liquefaction potential index susceptibility mapping for a liquefaction - prone area (Inegol - Turkey), Environmental Geology, 44, 862-871.

Yuan, H., Yang, S.H., Andrus, R.D. and Juang, C.H., 2003. Liquefaction-induced ground failure: a study of the Chi-Chi earthquake cases, Engineering Geology, 17, 141-155. 